\title{
Residential location choice and its effects on travel satisfaction in a context of short-term transnational relocation
}

\author{
Mayara Moraes Monteiro \\ University of Porto \\ Technical University of Denmark \\ maymmo@dtu.dk \\ Nuno Afonso \\ University of LIsbon \\ nuno.fnvs.afonso@gmail.com \\ Jorge Pinho de Sousa \\ University of Porto \\ jorge.p.sousa@inesctec.pt
}

\author{
João de Abreu e Silva \\ University of LIsbon \\ jabreu@tecnico.ulisboa.pt \\ Jesper Bláfoss Ingvardson \\ Technical University of Denmark \\ jbin@dtu.dk
}

Abstract: Temporary opportunities for studying and working abroad have been growing globally and intensifying the movement of highly skilled temporary populations. To attract this group, cities need to address their residential and mobility needs. This study focuses on factors influencing residential and travel satisfaction of transnational temporary residents, highlighting the occurrence of residential selfselection, its impacts on residential and travel choices and on derived levels of satisfaction. We have estimated a Bayesian Structural Equations Model and found that lower levels of residential satisfaction (residential dissonance) are associated with lower rents, living farther away from the place of study or work, and having higher transport expenditures. In contrast, higher levels of residential satisfaction (residential consonance) are related to individuals' stronger preferences for active modes, lower levels of public transport use, and reduced transport monthly expenditures, which suggest shorter commuting distances. These findings reveal the tradeoffs involving residential location, monthly rent, and transport expenditures, highlighting that providing good public transport connections can reduce the burden of commuting distances. Our results indicate that better transport supply and land-use balance near the residence can improve both residential and travel satisfaction.

Keywords: Temporary residents, transnational relocation, residential location choice, residential satisfaction, travel satisfaction.

\section{Article history:}

Received: January 6, 2021

Accepted: March 25, 2021

Available online: September 15, 2021

\section{$1 \quad$ Introduction}

Temporary opportunities for studying and working abroad have been growing globally (OECD, 2019; UNESCO, 2020) and intensifying the movement of highly skilled temporary populations. Universi-

Copyright 2021 Mayara Moraes Monteiro, João de Abreu e Silva, Nuno Afonso, Jesper Bláfoss Ingvardson \& Jorge Pinho de Sousa http://dx.doi.org/10.5198/jtlu.2021.1952

ISSN: 1938-7849 | Licensed under the Creative Commons Attribution - Noncommercial License 4.0

The Journal of Transport and Land Use is the official journal of the World Society for Transport and Land Use (WSTLUR) and is published and sponsored by the University of Minnesota Center for Transportation Studies. 
ties, as well as cities, are acting to attract talents who bring knowledge and revenues, generating positive economic and societal impacts (Findlay, 2011; Kuptsch \& Pang, 2006; Riańo \& Piguet, 2016). Understanding residential and travel needs of these temporary highly skilled residents, who are likely to rely more on public transport, shared mobility services, and housing rentals, is essential to attract them. Recognizing their needs is also important since their choices affect services and real estate markets in cities, either by contributing to higher levels of crowdedness in public transport or increasing housing prices, therefore distressing other residents.

When relocating internationally, individuals need to adapt to the new temporary environment at the same time that their mobility habits are broken (following this key event). Their ephemeral perspective influences their mobility choices, making them less likely to invest in private modes when compared to long-term residents (Burbidge, 2012; Glover, 2011), resulting in a higher likelihood of relying on public transport and active modes for their mobility. Also influencing their mobility, their residential location choice in the host city determines the starting or ending point of several trips and, consequently, defines, to some extent, individuals' mobility opportunities and constraints. It is reasonable to assume that their prior knowledge about the workplace/university location (assumed to be fixed during their stay) provides them with insights about their preferred residential location (Monteiro et al., 2021). However, their decisions are made in a stage of inexistent or very limited familiarity with the new city and little to no knowledge of its neighborhood features. Thus, studying their mobility and residential decisions and the perceived satisfaction associated to these choices is also relevant from a behavioral perspective, as it allows for observing decision making mechanisms after the occurrence of simultaneous key events and in the presence of only limited information, and the satisfaction derived from these choices.

In general, the literature on temporary international migrants disregards the relationships between residential location and travel choices, whose existence in other contexts is stressed by several studies (de Abreu e Silva and Goulias, 2009; De Vos, Derudder, van Acker, \& Witlox, 2012; Langlois, van Lierop, Wasfi, \& El-Geneidy, 2015; Schwanen \& Mokhtarian, 2007). To the best of our knowledge, the literature on mobility biographies has not examined the impacts of simultaneous changes in residential location, accessibility levels, private mode availability, and mobility culture. Moreover, the resultant individual satisfaction with residential location and travel behavior has not been explored so far.

Thus, this study has three main contributions: (i) to the literature on mobility biographies, as it sheds light on the impact of simultaneous key events and limited information on mobility choices; (ii) to the literature on travel behavior and residential choice, as it analyses the relationship between these choices in the particular context of short-term residents; (iii) to city planning, as the results can help cities to attract international talents and to be better prepared for their continuous housing and transportation demands while maintaining the well-being of other residents (Bergstad et al., 2011).

The remainder of this paper is structured as follows. Section 2 reviews the literature on residential location, travel choices and residential and travel satisfaction. Section 3 presents the hypotheses investigated in this study. Section 4 describes the survey design, data collection, and the modeling approach used. Section 5 presents the resulting model and its associated fit indices. Section 6 discusses the results, presenting considerations about its possible extensions and limitations.

\section{Literature review}

\subsection{Residential location and travel choices}

The literature on residential location choice highlights a concept that connects it with travel choices: self-selection, which is the propensity of an individual to choose a residential location aligned with his/ 
her travel abilities, needs, and preferences (Litman, 2007). The influence of transport-related attitudinal factors/preferences on residential location choice and travel behavior is empirically evidenced in several studies (Chatman, 2009; de Abreu e Silva, 2014; van Acker, Mokhtarian, \& Witlox, 2011; Wolday, Næss, \& Cao, 2019).

After relocating to a place better aligned with their travel preferences, making possible the fulfillment of an intended behavior, people may change their behavior, even if they do not change their attitudes (Manaugh \& El-Geneidy, 2015). However, as not everyone manages to live in a place that meets their travel preferences, they might face difficulties in trying to travel by their preferred mode (De Vos, 2019). Milakis, Efthymiou, and Antoniou (2017) found that people who have relocated internationally to places with underdeveloped transport infrastructures faced a lack of safe conditions with adopting active modes, which negatively influenced their use. These cases lead to low levels of travel satisfaction since people are forced to move around using a mode that is not their preferred option (De Vos, Mokhtarian, Schwanen, van Acker \& Witlox, 2016).

There is still no definitive consensus on whether people choose their residential place based on the transportation preferences (self-selection) or if the residential place defines their travel behavior or attitudes (Scheiner, 2014; Wang \& Lin, 2019). However, the effects of the new built environment on travel preferences may only occur after an individual has been living for a prolonged time in the new place (De Vos, Ettema, \& Witlox, 2018).

Nevertheless, accounting for self-selection while examining the causal relationship between residential location and travel behavior does not change the nature of its influence, which exists independently of the incidence of self-selection (Næss, 2014).

\subsection{Residential location satisfaction}

Residential satisfaction refers to what extent the demands and desires of a person match with their current residence (Lu, 1999). There is no standard way of measuring residential satisfaction. Several studies have approached it in different ways: (i) under a broader/general perspective (Barreira, Nunes, Guimarães, \& Panagopoulos, 2019), (ii) focusing on neighborhood attributes (De Vos et al., 2012; Lovejoy, Handy, \& Mokhtarian, 2010), (iii) looking at the house unit level features (Dinç, Özbilen, \& Bilir, 2014), and (iv) considering both neighborhood and housing attributes (Adriaanse, 2007). Thus, the attributes used to measure residential satisfaction vary, usually including features of physical, social, and economic environments, location and accessibility, and the existence of facilities and services (Lovejoy et al., 2010).

Accessibility to services, goods, and to the city center are locational attributes that are, at the same time, important components for the residential location choice (Frenkel, Bendit, \& Kaplan, 2013), and residential satisfaction (Buys \& Miller, 2012; Lotfi, Despres, \& Lord, 2019). The literature highlights that access to recreational opportunities/facilities (Chapman \& Lombard, 2006; Hur \& Morrow-Jones, 2008; Lotfi et al., 2019), to shopping, restaurants, and cafés (Chadbourne, 2014), and to the city center (Bonaiuto, Fornara, \&, Bonnes, 2003) contributes positively to neighborhood satisfaction.

Proximity to public transport was found to impact residential satisfaction: the closer to public transport people live, the higher their residential satisfaction (Lotfi et al., 2019). One-way commuting distance to workplace/place of study was also found as impacting residential satisfaction; the closer to workplace one lives, the higher the residential satisfaction (Chadbourne, 2014; Hur \& Morrow-Jones, 2008).

Additionally, the definition of residential dissonance, as expressing discrepancy between the actual and preferred residential characteristics, approximates this idea to the concept of residential satisfaction (Schwanen \& Mokhtarian, 2004). Both dissonance and satisfaction can characterize the mental state of an individual in a complementary way (Salzberger \& Koller, 2010). As low satisfaction levels are associ- 
ated with a dissonant state (Schwanen \& Mokhtarian, 2004), and residential dissonance leads to lower levels of travel satisfaction (De Vos et al., 2016), it is reasonable to say that low residential satisfaction can result in lower levels of travel satisfaction.

\subsection{Travel satisfaction}

There is a general agreement in the literature that public transport users, especially in the case of buses, tend to present lower levels of travel satisfaction, as opposed to people who use active modes, which display the highest levels of travel satisfaction (De Vos, 2019). Manaugh and El-Geneidy (2013) found that higher travel satisfaction levels are associated with underlying motivations to use active modes, such as the desire to exercise, environmental concerns, and the aesthetic appreciation of the journey. The lower satisfaction levels experienced by public transport users may be due to the relatively higher number of elements that are out of the control of the users (e.g., travel time, waiting time, congestion, coverage) (St-Louis, Manaugh, van Lierop, El-Geneidy, 2014). This low satisfaction might be the consequence of exposure to critical issues that mark people's perception as a generalization of public transport travel experience (Friman \& Gärling, 2001; Guiver, 2007) or even an effect derived from forced use due to budget constraints (Beimborn, Greewald, \& Jin, 2003).

On the one hand, De Vos (2019) argues that travel satisfaction is impacted by residential location choice through travel attitudes and mode choice. On the other hand, Cao and Ettema (2014) found that even after controlling for the effect of residential self-selection on travel behavior satisfaction, built environment characteristics have an independent impact on travel satisfaction. High levels of travel satisfaction are associated with high accessibility to public transport (Cao, 2013; Chowdhury, Zhai, \& Khan, 2016). Regardless, controlling for self-selection is necessary as it avoids miscalculation of the effects of built environment on travel behavior (Chatman, 2009).

Regarding other locational-related effects, while Olsson, Gärling, Ettema, Friman, \& Fujii (2013) found that longer distances result in decreased satisfaction with commuting, Redmond and Mokhtarian (2001) and Ory et al. (2004) found that people prefer commutes that are not too long nor too short.

\section{$3 \quad$ Hypotheses}

The findings from the reviewed literature led us to define the following hypotheses to be tested:

H1: Self-selection occurrence: travel preferences influence both residential location choice and transport mode choice (Chatman, 2009; de Abreu e Silva, 2014; van Acker et al., 2011; Wolday et al., 2019). Due to the short-term perspective, temporary residents are unlikely to invest in expensive private modes, thus having to rely either on public transport or active modes (Monteiro et al., 2021). Thus, the residential location choice plays an important role since the distance to the workplace will, to some extent, define which transport modes are available. Travel preferences are likely to have a significant effect on residential location, namely in terms of the distance to the workplace. However, their effects on land use related attributes of the residential location will probably be less pronounced due to a lack of sufficient knowledge to self-select to specific neighborhoods/areas.

H2: Residential location features influence travel behavior (de Abreu e Silva, 2014; Milakis et al., 2017) and residential satisfaction (Buys \& Miller, 2012; Lotfi et al., 2019). The higher the accessibility to public transport, the higher the frequency of public transport use. This, combined with a good landuse mix, increases residential satisfaction.

H3: One-way commuting distance to workplaceluniversity is negatively associated with both residential (Chadbourne, 2014; Hur \& Morrow-Jones, 2008) and travel satisfaction (Olsson et al., 2013). Know- 
ing that the workplace will likely be the most frequent destination, an increase in commuting distance will negatively impact both residential and travel satisfaction.

H4: Low residential satisfaction can result in lower levels of travel satisfaction. Residential dissonance is likely to be highly impacted by unmet travel preferences, and therefore a lower residential location satisfaction can result in lower travel satisfaction.

H5: Mode choice influences travel satisfaction (De Vos et al., 2016). The use of active modes increases travel satisfaction, whereas public transport use has a contrary effect.

H6: Residential location features have a direct independent impact on travel satisfaction (Cao, 2013; Cao \& Ettema, 2014; Chowdhury et al., 2016). High accessibility of public transport is associated with high levels of travel satisfaction.

In figure 1, the above hypotheses, that will be tested and aid the model development, are summarized.

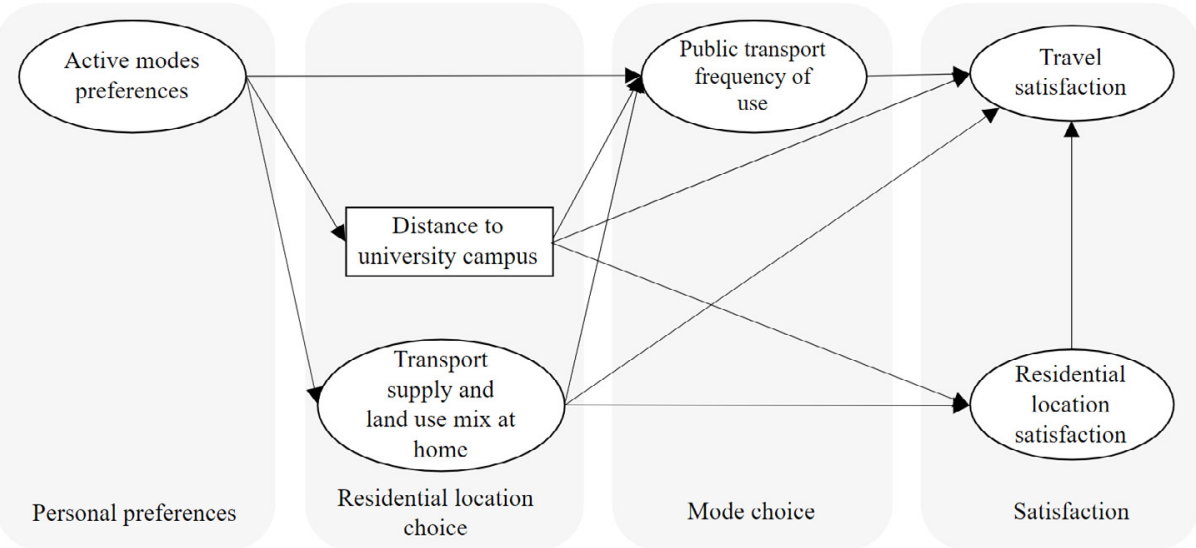

Figure 1. Theoretical framework with hypothetical relationships to be tested

\section{$4 \quad$ Methods and data}

\subsection{Survey design and data collection}

To explore the relationships between residential location and travel preferences, as well as the derived satisfaction, we collected data through a tailor-made online survey. Its design was based on the literature review and the results from previous analyses and models developed to explore the residential location and travel satisfaction of short-term residents.

The online questionnaire comprised questions about socioeconomic characteristics, individuals' residential locations in Porto, active modes preference, frequency of use of public transport and active modes, residential satisfaction, and travel satisfaction. The socioeconomic questions included age, gender, driver's license ownership, role at the university, country of origin, residential location at the city of origin (central area, urban area, suburban area, or outside in the rural areas or in a village), elapsed time in Porto, duration of the stay in Porto, the campus of the University of Porto where the respondent studies/works, accommodation type, rent price, and monthly transport expenditure.

To characterize the land use and public transport supply at respondents' residential locations in the Greater Porto Region, several indicators were built. For this, we have extracted and combined information based on the stated residence location. Using geocoding tools on Google and Bing Maps, we obtained the geographic coordinates (latitude and longitude) of each stated place of residence. The 
land-use indicators describing residential location features were calculated considering a buffer area of $400 \mathrm{~m}$ radius (using a straight line distance), centered on each respondent's residential location, which is traditionally considered as the average walking distance to neighborhood destinations people are willing to walk (Aultman-Hall, Roorda, \& Baetr, 1997). For each residential location, we extracted data from the 2011 census (Instituto Nacional de Estatística, 2012) on the number of accommodations, and from Open Street Maps on public transport (metro and bus), number and type of roads, retail, services, and places of leisure. Although the simplification in the buffer area definition may lead to underestimation of route distances and overestimation of local accessibility, the literature has pointed that individuals may be willing to walk more than $400 \mathrm{~m}$ for amenities and transport (El-Geneidy, Grimsrud, Wasfi, Tetreault, Surprenant-Legault, 2014; Gunn et al., 2017; Páez, Scott, \& Morency, 2012). An entropy index was also calculated to characterize better the land-use balance surrounding each residential location (Kockelman, 1997):

$$
\text { Entropy }=\sum_{j} \frac{\left|P_{j} \mathrm{x} \ln \left(P_{j}\right)\right|}{\ln (J)}
$$

where $P_{j}$ is the proportion of places of type $\mathrm{j}$, and $J$ is the number of categories. This indicator varies from zero to one, "zero" representing the presence of only one type of activity and "one" describing a homogeneous balance of types. We have considered the existence of 4 types: housing, commerce, service, and leisure places.

Preference for active modes was elicited in terms of preferences related to perceived health, environmental benefits, and convenience of use. This factor was used as a proxy to control for residential self-selection.

Knowing that temporary residents in Porto mainly travel by public transport and/or active modes, we defined the factor "Public transport frequency of use" to characterize the travel behavior of respondents. It was measured by combining the self-reported frequencies of public transport and active modes for all trip purposes. Beyond the frequencies of bus and metro use, an indicator was built to characterize the public transport use relative to the active modes use, according to the most frequently used mode(s). For this, an ordered variable with three levels was created: (1) composed by those who travel mostly using only active modes; (2) composed by those whose majority of travels is performed by a combination of active modes and public transport modes; and (3) composed by those who travel mostly using only by public transport. Thus, a high load on this factor ("Public transport frequency of use") indicates a high frequency of traveling only by public transport, and a low load on this factor is associated with a high frequency of traveling only by active modes.

Residential satisfaction was measured according to the locational perspective of the current study and encompassed the evaluation of accessibility to places of entertainment, leisure, services, and goods, and perceived easiness in reaching the city center. Travel satisfaction was measured by means of the Satisfaction with Travel Scale (STS), defined by Bergstad et al. (2011). The STS does not focus on any specific travel mode but rather evaluates the perceived features of daily travels. It includes whether the positive aspects related to daily traveling outweigh the negative aspects, whether there is some desire for changes in daily travels, and which are the perceived advantages of daily traveling.

The questions associated with the indicators for the latent constructs were graded in a 5-point Likert scale from "strongly disagree" to "strongly agree," except the ones related to satisfaction that were graded in a 5-point Likert scale from "very dissatisfied" to "very satisfied."

The survey was disseminated among international students and researchers, through email, by the University of Porto International Office. The survey was available both in English and Portuguese between July and August of 2019, taking about 15 minutes to complete. 


\subsection{Sample characteristics}

Table 1 summarizes the sample characteristics of the 206 respondents that completed the questionnaire. Most of the respondents are women, have a driver's license, are between 18 and 25 years old, are from America (mostly from Brazil), are undergraduate students, live up to $2.5 \mathrm{~km}$ from the university, and are frequent users of public transport or travel by foot. Note that, as most of the respondents exhibit a multimodal travel behavior, the sum of percentages presented for frequent users of different modes exceeds $100 \%$. As the University of Porto offers only a limited number of accommodations to foreign students and researchers, the majority of them rely on the private housing market.

Table 1. Sample characteristics

\begin{tabular}{|c|c|c|}
\hline Variables & Total & $\%$ \\
\hline \multicolumn{3}{|l|}{ Gender } \\
\hline Male & 76 & $36.89 \%$ \\
\hline Female & 130 & $63.11 \%$ \\
\hline \multicolumn{3}{|l|}{ Age } \\
\hline Between $18-25$ years & 135 & $65.53 \%$ \\
\hline Between 26-30 years & 42 & $20.39 \%$ \\
\hline Between $31-40$ years & 23 & $11.17 \%$ \\
\hline More than 40 years & 6 & $2.91 \%$ \\
\hline \multicolumn{3}{|l|}{ Continent of origin } \\
\hline Africa & 9 & $4.37 \%$ \\
\hline America & 104 & $50.49 \%$ \\
\hline Asia & 15 & $7.28 \%$ \\
\hline Europe & 78 & $37.86 \%$ \\
\hline Oceania & 0 & $0.00 \%$ \\
\hline \multicolumn{3}{|l|}{ Role at the University } \\
\hline Bachelor student & 75 & $36.41 \%$ \\
\hline Master student & 40 & $19.42 \%$ \\
\hline Integrated master student & 40 & $19.42 \%$ \\
\hline $\mathrm{PhD}$ student & 38 & $18.45 \%$ \\
\hline Post-doc & 4 & $1.94 \%$ \\
\hline Researcher & 9 & $4.37 \%$ \\
\hline \multicolumn{3}{|l|}{ Distance home - university campus } \\
\hline Live up to $2.5 \mathrm{~km}$ from the University & 109 & $52.91 \%$ \\
\hline Live between $2.5 \mathrm{~km}$ and $5 \mathrm{~km}$ from the University & 79 & $38.35 \%$ \\
\hline Live between $5 \mathrm{~km}$ and $10 \mathrm{~km}$ from the University & 16 & $7.77 \%$ \\
\hline Live more than $10 \mathrm{~km}$ from the University & 2 & $0.97 \%$ \\
\hline \multicolumn{3}{|c|}{ Moment when respondents have searched for their residence in Porto } \\
\hline Before moving to Porto & 154 & $74.76 \%$ \\
\hline After have moved to Porto & 44 & $21.36 \%$ \\
\hline Have not chosen (moved to live with family or friends) & 8 & $3.88 \%$ \\
\hline University halls vs. private & & \\
\hline
\end{tabular}




\begin{tabular}{|lll|}
\hline Variables & Total & $\%$ \\
\hline University accommodation & 13 & $6.31 \%$ \\
Private accommodation & 193 & $93.69 \%$ \\
\hline Frequent users (2 or more days a week) & & \\
\hline Car & 10 & $4.85 \%$ \\
Public transport & 154 & $74.76 \%$ \\
Bike & 12 & $5.83 \%$ \\
Walking & 193 & $93.69 \%$ \\
\hline Density (km $\left.^{2}\right)$ & Mean & Std. Deviation \\
\hline Housing & 7550.43 & 2521.93 \\
Places of commerce & 27.94 & 69.08 \\
Places of services & 11.52 & 22.09 \\
Places of leisure & 35.06 & 67.07 \\
\hline
\end{tabular}

Regarding the characterization of land use around the residential location of respondents, figures $2 \mathrm{a}, 2 \mathrm{~b}, 2 \mathrm{c}$, and $2 \mathrm{~d}$ present how many respondents have access to the specified number of accommodations, commerce, services, and places of leisure in a $400 \mathrm{~m}$ radius from home. Overall, respondents live in dense residential areas, having at least 847 accommodations in a $400 \mathrm{~m}$ radius from home. Considering this radius, around $56 \%$ can find at least four places of commerce, $35 \%$ can find at least four places of service, and $60 \%$ can find at least four places of leisure.

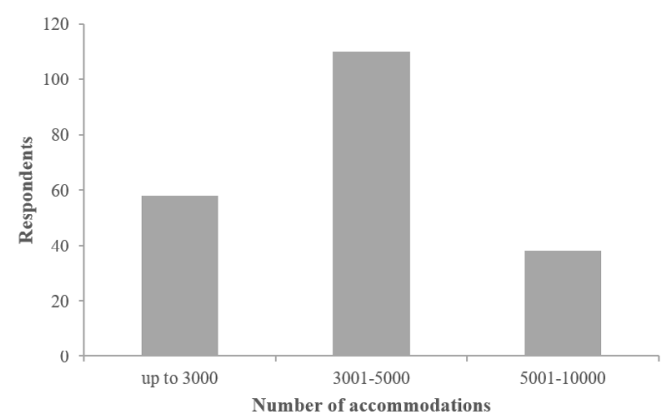

Figure 2a. Number of accommodations that respondents have access to in a $400 \mathrm{~m}$ radius from their residential location

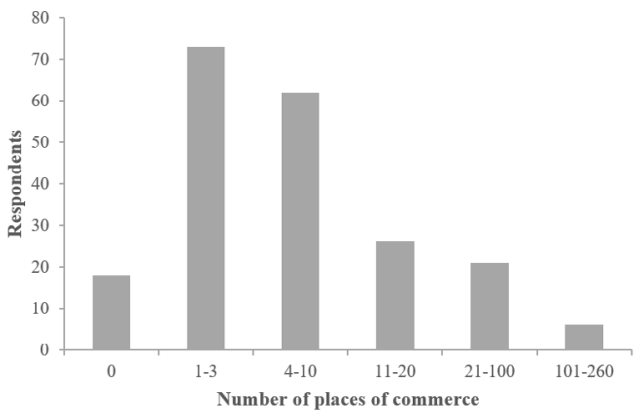

Figure 2c. Number of services that respondents have access to in a $400 \mathrm{~m}$ radius from their residential location

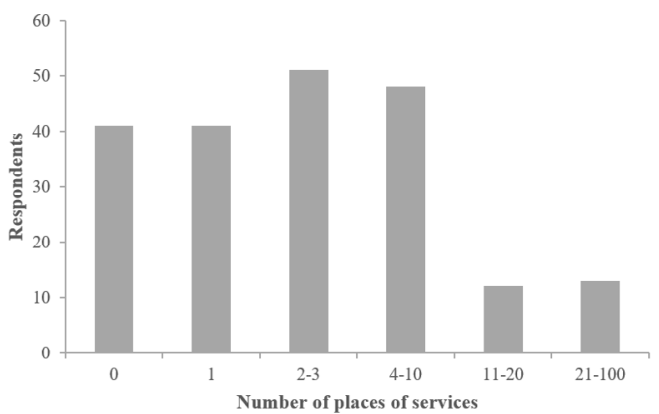

Figure 2b. Number of places of commerce that respondents have access to in a $400 \mathrm{~m}$ radius from their residential location

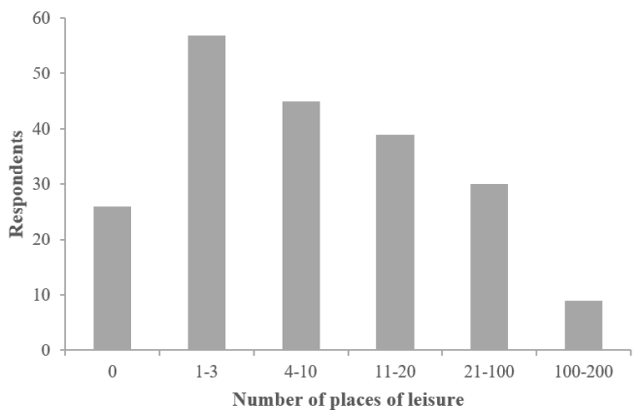

Figure 2d. Number of places of leisure that respondents have access to in a $400 \mathrm{~m}$ radius from their residential location 


\subsection{Methodology}

To assess the relationship between the factors and the socioeconomic variables, a Structural Equations Model (SEM) was implemented in MPlus (Muthén \& Muthén, 2017) using Bayesian estimation (BSEM). This approach presents a better performance for small samples, as it does not rely on largesample theory (Muthén \& Asparouhov, 2012). Identically to the process of using a frequentist method for estimating a structural equation model, we performed an exploratory factor analysis to study the underlying structure among both the latent constructs and the objective measures of land-use mix at the residential location. We also tested the sample adequacy (Kaiser-Meyer-Okin measure - KMO) and the internal consistency (Cronbach's alpha) of the data and extracted factors.

We have applied the BSEM approach described in Muthén and Asparouhov (2012), which consists of systematically set small-variance informative priors in the measurement model for cross-loadings $\left(\alpha_{r}\right)$, constraining those priors to be close to zero, rather than to set them to zero or allow them to be freely estimated. This adjustment in the measurement model allows the model to better reflect the theory (Muthén \& Asparouhov, 2012). After conducting a sensitivity analysis for the informative priors for the cross-loadings, we have chosen to define the priors as normally distributed with a mean equal to zero and variance of 0.009 .

Based on these results, we estimated the measurement model or confirmatory factor analysis model to examine the relationships between observed variables and latent variables. In this study, the model consists of four sets of equations. Equation 2 refers to the measurement equations, Equation 3 connects the latent variables to individuals socioeconomic characteristics, Equation 4 links the explanatory and the mediator latent variables, and Equation 5 connects the latent mediators to the dependent variable:

$$
\begin{aligned}
& \mathrm{I}_{r n}=\mathrm{Z}_{l n}^{*} \alpha_{r}+v_{r n} \text { and } v_{n} \sim \mathrm{N}\left(0, \Sigma_{v}\right) \text { for } r=1, \ldots, R \\
& \mathrm{Z}^{*}{ }_{l n}=\mathrm{S}_{l n} \beta_{l}+\omega_{l n} \text { and } \omega_{n} \sim \mathrm{N}\left(0, \Sigma_{\omega}\right) \text { for } l=1, \ldots, L \\
& \mathrm{Z}_{l}^{*}=\mathrm{Z}_{i} \beta_{i}+\varphi_{l} \text { and } \varphi_{l} \sim \mathrm{N}\left(0, \Sigma_{\varphi}\right) \text { for } l=1, \ldots, L \& i=1, \ldots, I \\
& \mathrm{Y}_{i n}=\mathrm{Z}^{*}{ }_{l n} \gamma_{Z}+\xi_{n} \text { and } \xi_{n} \sim \mathrm{N}\left(0, \Sigma_{\xi}\right) \text { for } i=1, \ldots, I
\end{aligned}
$$

where $I_{r n}$ is a vector of indicators $r$ of the latent constructs as perceived by individuals $n, \alpha_{r}$ is a matrix of factor loadings and $v_{r n}$ is a random vector of measurement (residual) errors which follow a normal distribution with covariance matrix $\Sigma_{v}, \mathrm{Z}_{l n}^{*}$ is a vector containing the latent variables, $\mathrm{S}_{l n}$ is a vector of individuals' socioeconomic characteristics, $\mathrm{Z}^{*}$, refers to the mediator latent construct and $\mathrm{Z}_{i}$ refers to the explanatory latent construct. $\beta_{l}$ and $\beta_{i}$ contains parameters that reflect directed paths between sociodemographic variables and latent variables and among exploratory and mediator latent variables, respectively. $\omega_{l n}$ and $\varphi_{l}$ are error terms vectors, which follow a normal distribution with respective covariance matrix $\Sigma_{\omega}$ and $\Sigma_{\varphi}$. $Y_{i n}$ is the dependent variable, $\gamma_{Z}$ is the parameter that represents the regression relations between the latent variables and the dependent variable, and $\xi_{n}$ is a vector of error terms which follow a normal distribution with covariance matrix $\Sigma_{\xi}$

The structural model was developed to test the existence of relationships between factors and observed variables that are not factor indicators (sociodemographic variables) as well as the relationships among the latent variables, according to Equations 3, 4, and 5.

The model goodness-of-fit was assessed by the Posterior Predictive P-value (PPP), which is based on chi-square but is less sensitive than likelihood-ratio chi-square to ignorable degrees of model misspecifcation (Muthén \& Asparouhov, 2012). An acceptable fit corresponds to a PPP value above 0.05, and an excellent-fitting model corresponds to a PPP value of around 0.5 (Muthén \& Asparouhov, 2012). 


\section{$5 \quad$ Results}

\subsection{Exploratory and confirmatory factor analysis}

The results from the exploratory factor analysis (EFA) indicate good sampling adequacy (KMO $=0.761)$. The result of Bartlett's test of sphericity allows us to reject the null hypothesis that the correlation matrix is an identity matrix $(\mathrm{p}=0.000)$, and the determinant of the correlation matrix equal to 0.001 indicates the absence of multicollinearity (Prato, Bekhor, \& Pronello, 2005). The extracting method used was principal axis factoring based on Eigenvalues greater than 1 with varimax rotation (Kaiser normalization). The results indicated the existence of 5 factors (see table 2), which was supported by the scree plot that levels off after that, and by the theory, since the grouped items have a theoretical meaning (Hair, Black, Babin, \& Anderson, 2014). The resulting five factors represent latent variables and composite measures: active modes preference, residential location satisfaction, public transport frequency of use, travel satisfaction and transport supply, and land-use mix at the residential location. The dominant items (marked in bold) were defined considering a cut-off value of 0.4 , which is adequate to the sample size (Hair et al., 2014). The Cronbach's alpha values of each factor are presented inside parentheses and indicate moderate to excellent internal consistency (Hinton, McMurray, \& Brownlow, 2014).

The confirmatory factor analysis validated the factor model construction (see table 2). As we implemented the BSEM approach described in Muthén and Asparouhov (2012), the estimates for the measurement equations include small-cross loadings between the indicators of the other factors, which are constrained to be close to zero, resulting in a structure similar to the EFA output. It is worth mentioning that the results of the confirmatory factor analysis do not include any significant cross-loading between factors but rather small non-significant cross-loadings that allow for an analysis that better reflects the substantive theories. Note that, despite the similarity, the model is regulated, and the cross-loadings are restricted to small values through the specification of priors (Muthén \& Asparouhov, 2012). We have highlighted in bold the factor loadings for which the $95 \%$ credibility interval does not contain zero, making it easy to observe the structure defined for the factors in the confirmatory analysis. The Posterior Predictive P-Value (PPP) is 0.289 , indicating a good fit of the results of the confirmatory factor analysis. 


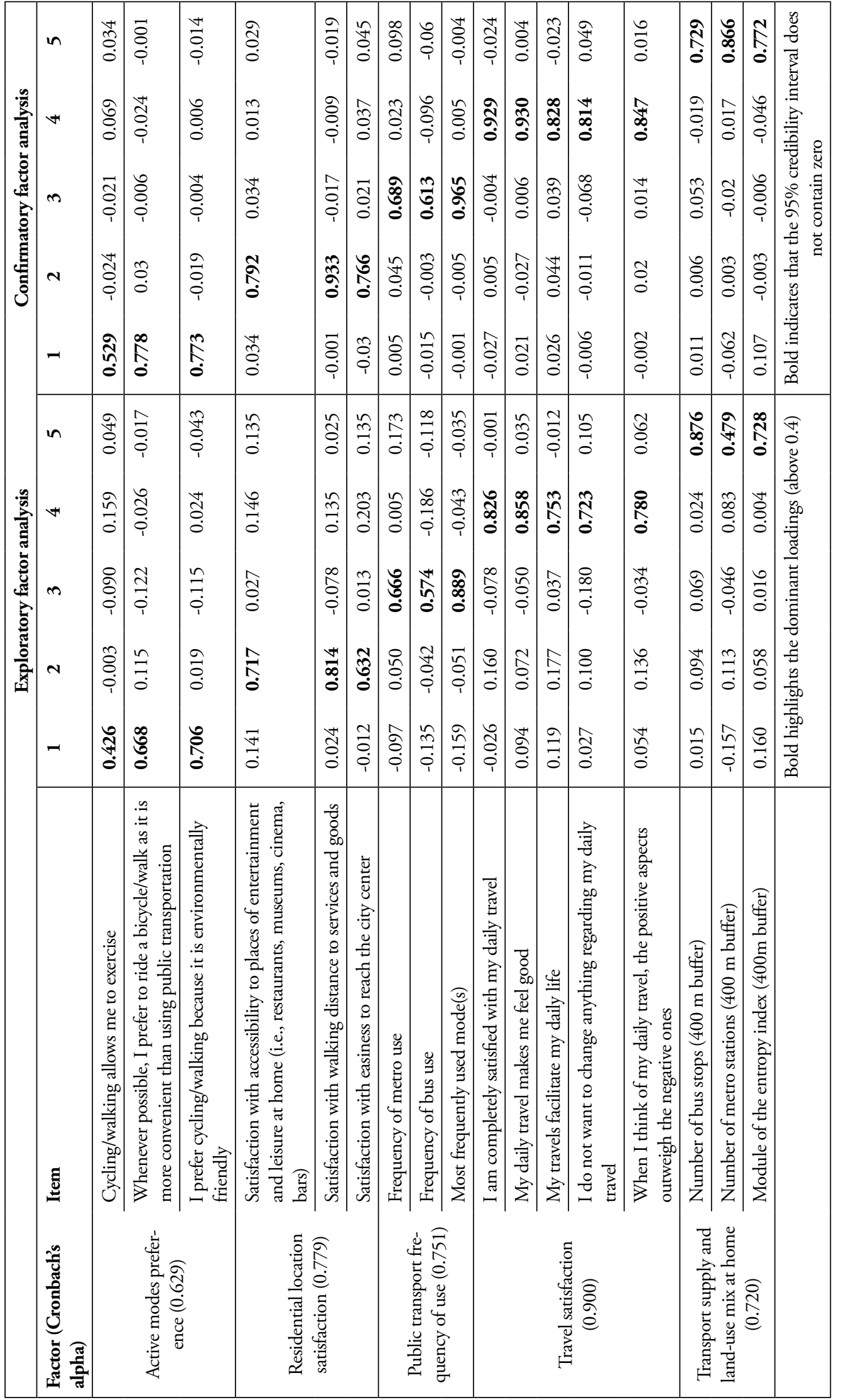


The structural model was estimated (see tables 3 and 4) to assess the existence of the relationships between the latent constructs and respondents' characteristics and the relationships between the latent constructs (with respondents' characteristics already associated). The model was developed according to the theoretical underpinnings presented in section 2 , and the relations tested are those described in section 3 and summarized in the theoretical framework presented in Figure 1. Among the relationships tested that could offer insights for understanding individuals' choices, behavior, and satisfaction, only those which were found to be significant at least at a $90 \%$ credibility interval were kept in the model. The PPP-Value of the complete model is 0.595, indicating an excellent fit (Muthén \& Asparouhov, 2012).

Table 3. Standardized estimates of SEM relating respondents' characteristics and latent constructs

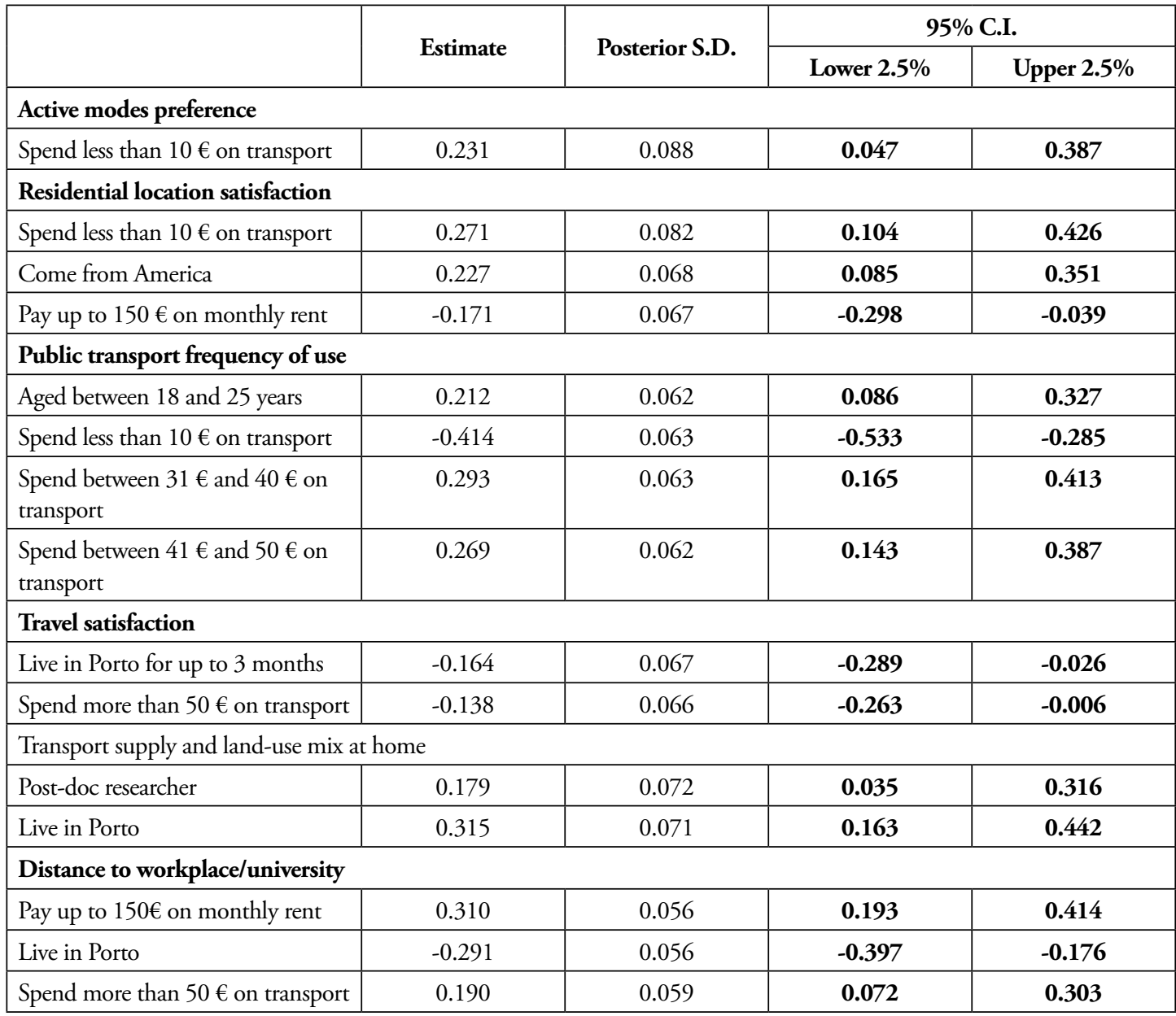

C.I. stands for credibility interval

Bold indicates that the credibility interval does not contain zero

As for respondents' characteristics found to be significantly associated with the latent constructs, those who have between 18 and 25 years tend to travel more by public transport and walk less. The respondents that come from America (mostly from Brazil) presented higher levels of residential satisfaction than people from any other continent, and post-doc researchers were found to be more likely to live in places better served by public transport and with more diversity of land uses.

Not surprisingly, those who spend less than $10 €$ on transport a month are those who have stron- 
ger preferences for active modes, lower levels of public transport use, and higher satisfaction with their residential location. Their higher residential satisfaction could be the result of living in a place where one can access many places within walking distance. Additionally, respondents who spend between 31 $€$ and $50 €$ on transport a month are those who use public transport more, and those who spend more than $50 €$ on transport are those who live further from their workplace/university and are less satisfied with their travels. These results are in accordance with De Vos (2019), who found that a higher level of public transport use is associated with lower levels of travel satisfaction. Individuals that pay up to 150 $€$ for monthly rent were found to be less satisfied with the residential location and more likely to live away from the workplace/university. Those living in Porto have better transport supply and more diverse neighborhoods, being, of course, closer to the workplace/university. Interestingly, those who were living in Porto for up to 3 months by the time of the survey exhibited lower levels of travel satisfaction. This can be associated with initial difficulties in using/understanding a still unfamiliar public transportation system.

Table 4. Standardized estimates of structural equations relating latent constructs

\begin{tabular}{|c|c|c|c|c|c|c|}
\hline & \multirow[b]{2}{*}{ Estimate } & \multirow{2}{*}{$\begin{array}{l}\text { Posterior } \\
\text { S.D. }\end{array}$} & \multicolumn{2}{|c|}{ 95\% C.I. } & \multicolumn{2}{|c|}{ 90\% C.I. } \\
\hline & & & $\begin{array}{c}\text { Lower } \\
2.5 \%\end{array}$ & $\begin{array}{l}\text { Upper } \\
2.5 \%\end{array}$ & Lower 5\% & Upper 5\% \\
\hline \multicolumn{7}{|l|}{ Distance to workplace/university } \\
\hline Active modes preference & -0.152 & 0.071 & -0.286 & -0.008 & & \\
\hline \multicolumn{7}{|l|}{ Public transport frequency of use } \\
\hline Active modes preference & -0.176 & 0.092 & -0.357 & 0.005 & -0.327 & -0.022 \\
\hline $\begin{array}{l}\text { Transport supply and land-use mix } \\
\text { at home }\end{array}$ & 0.179 & 0.089 & 0.01 & 0.355 & & \\
\hline Distance to workplace/university & 0.191 & 0.065 & 0.061 & 0.318 & & \\
\hline \multicolumn{7}{|l|}{ Residential location satisfaction } \\
\hline $\begin{array}{l}\text { Transport supply and land-use mix } \\
\text { at home }\end{array}$ & 0.277 & 0.101 & 0.074 & 0.469 & & \\
\hline \multicolumn{7}{|l|}{ Travel satisfaction } \\
\hline Public transport frequency of use & -0.159 & 0.086 & -0.323 & 0.012 & -0.300 & -0.017 \\
\hline Residential location satisfaction & 0.299 & 0.081 & 0.138 & 0.451 & & \\
\hline
\end{tabular}

C.I. stands for credibility interval

Bold indicates that the credibility interval does not contain zero

Figure 3 shows the relationships between latent variables presented in table 4 in a more visual form (solid and dashed lines indicating positive and negative relationships, respectively). 


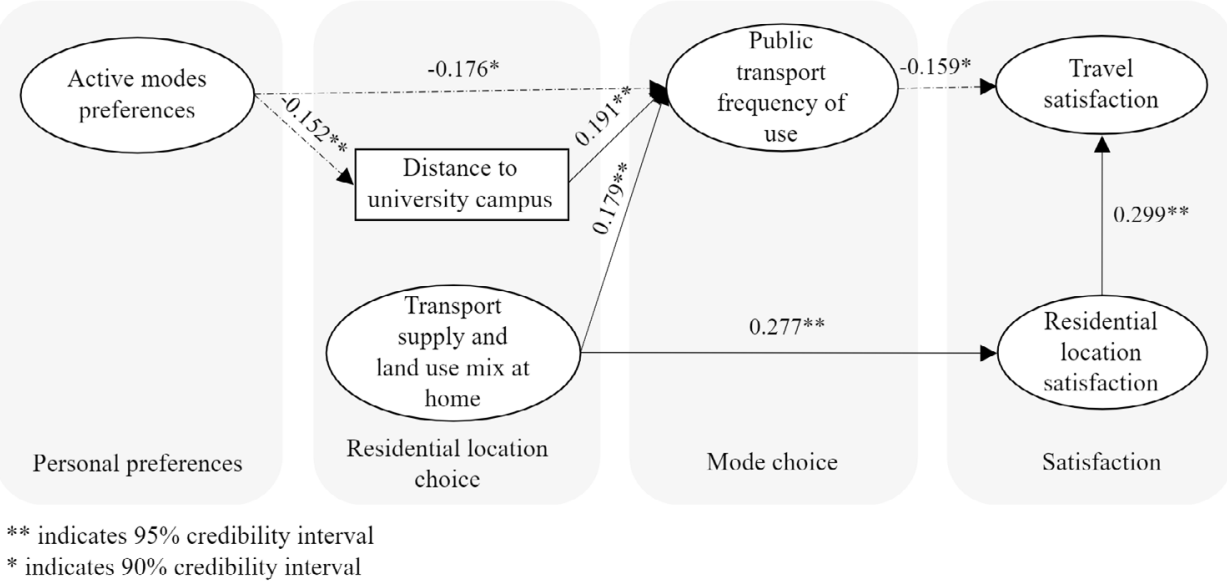

Figure 3. Model structure relating PT frequency of use and satisfaction with PT to the latent constructs

Based on the results, $\mathrm{H} 1$ is partially confirmed. Preference for active modes was found to be negatively associated with public transport frequency of use, as those people with higher pro-active modes preferences tended to use less public transport and walk more. Yet, only a limited effect of active modes preference on residential location was found significant. Higher pro-active travel preferences were associated with residential choices closer to the university/workplace, favoring the use of active modes for commuting. However, no connection with the levels of transportation supply and land-use balance could be established. Some explanations for that include: (i) workplace/university location being the only information respondents have by the time they chose the place to live (residential choice mainly occur before arriving at the host city); (ii) lack of sufficient knowledge on possible residential locations to allow proper self-selection; (iii) attachment of a higher value to proximity to the workplace instead of residential location accessibility/ indifference towards built environment attributes; and (iv) lower variability in the land-use characteristics (particularly residential density), since the places where the vast majority of respondents live are located within the urban core of Porto (see figure 4).

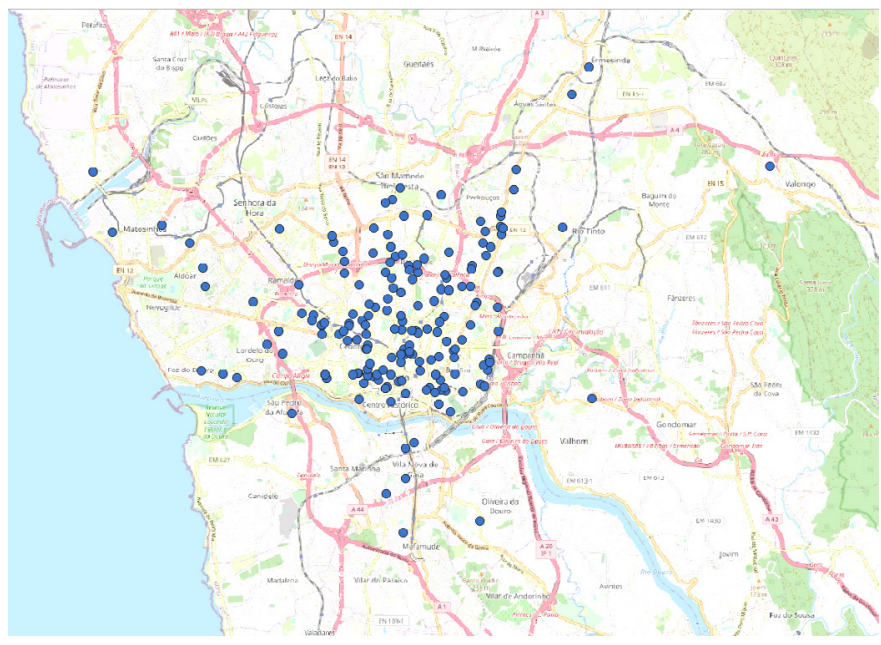

Figure 4. Residential location of respondents

$\mathrm{H} 2$ is confirmed, as the model supports the relationship between Transport supply and land-use mix (built environment) and travel behavior and the relationship between Transport supply and land-use mix 
and Residential location satisfaction. Living in a place with higher access to public transport is associated with more public transport use, and good public transport supply combined with good land-use balance at the residential location is associated with higher levels of residential satisfaction. These findings evidence the influence of the built environment on individuals' behavior and highlight the importance of access to a good supply of transport and amenities in residential satisfaction.

However, the model only partially confirms H3. Distance to workplace/university was not found to be significantly associated with residential satisfaction but to be significantly indirectly related to travel satisfaction. This negative indirect relationship is mediated by the public transport frequency of use and reveals that the further one lives from the university/workplace, the lower her/his travel satisfaction. It is reasonable to say that commuting distance impacts travel satisfaction because it affects both the commuting time and the transport mode choice set available. In other words, it defines whether an individual can consider using active modes to access the university/workplace (notably walk) or not.

The hypotheses $\mathrm{H} 4$ and $\mathrm{H} 5$ are confirmed since residential satisfaction and public transport frequency of use both influence travel satisfaction. Low residential satisfaction, which is associated with low levels of transport and amenities supplies, is linked to low travel satisfaction. Additionally, public transport users are connected with lower levels of travel satisfaction, which can be the result of (i) forced use, as temporary residents are assumed to rely on the existing mobility resources, or (ii) lower levels of control over different aspects of traveling (e.g., departure time, personal space).

Finally, the H6 is rejected, as residential location features presented no significant direct independent impact on travel satisfaction, being their positive relationship completely mediated by Residential location satisfaction (indirect effect $=0.081,95 \%$ credibility interval). Thus, modal choice and residential location satisfaction are the elements directly linked to travel satisfaction.

\section{Conclusions}

This study highlights the occurrence of residential self-selection and its impacts on residential and travel choices and on the derived level of satisfaction, focusing on factors influencing residential and travel satisfaction of transnational short-term residents.

We found that individuals presenting lower levels of residential satisfaction (dissonant residents) are those who pay lower rents. This is associated with living away from the university/workplace, with higher transport expenditures. Thus, the dissonant residential choice seems to be based on tradeoffs involving commuting distance, monthly rent, and transport expenses. The locational dissonance of those living further away than desired seems to occur due to budget constraints. However, as transport supply and land-use balance were found to directly influence residential satisfaction, it is unlikely that it is the distance itself that makes people less satisfied with their residential location. Rather the impact of budget constraints in the lower levels of accessibility to transport and different typologies of places seem to cause the lower residential satisfaction levels, as people could not properly self-select. Another possible cause for the residential location dissonance is that people do not have enough information on the options on transport supply and the land-use balance of the residential locations further from the university.

In contrast, individuals presenting higher residential satisfaction (consonant residents) have stronger preferences for active modes, lower levels of public transport use, and spend less than 10 euros on transport a month. These are indicatives of a residential location close to the university/workplace, favoring the use of active modes for commuting. As for their residential choice, it seems that the stronger the

preference for active travel one holds, the lower her/his sensitivity is to other features/tradeoffs that other residential location options offer.

For both cases, the model reveals that better transport supply and land-use balance at the home 
location can improve both residential and travel satisfaction. This may be possible through informing better short-term residents on these attributes for different neighborhoods so that they can avoid mismatch while choosing their residential place.

For city planners, it is important to identify workplaces that attract short-term residents so that people who self-select to live close to them can find a good infrastructure for walking or cycling, and those who do not manage to live close still can count on having a good public transport connection.

The model also evidences that the travel behavior of an individual reflects her/his travel preferences, spatial constraints (distances), and opportunities provided by her/his residential location as the starting point for travels. These results are in line with Næss (2005), that claims that incentives and deterrents for the pursuit of specific travel behaviors are implicit in the urban structure through the creation of proximities and distances between activities.

It would also be interesting to investigate the reasons why those who were living in Porto for up to 3 months, by the time of the survey, present lower levels of travel satisfaction. This may be the result of initial difficulties in traveling in an unfamiliar environment and system, which highlights the importance of making it easier for newcomers to navigate the city and to use public transport.

Finally, this study has some limitations due to the small sample size. The Bayesian Estimation for the Structural Equation Model assures the robustness of results, but a larger sample, including shortterm resident groups other than students/researchers, will hopefully demonstrate the transferability of these results.

\section{Acknowledgements}

The first author is funded by project NORTE-08-5369-FSE-000038, supported by the Northern Portugal Regional Operational Program (NORTE 2020), under the PORTUGAL 2020 Partnership Agreement, through the European Social Fund (ESF). 


\section{References}

Adriaanse, C. C. M. (2007). Measuring residential satisfaction: A residential environmental satisfaction scale (RESS). Journal of Housing and the Built Environment, 22(3), 287-304. https://doi. org/10.1007/s10901-007-9082-9

Aultman-Hall, L., Roorda, M., \& Baetr, B. W. (1997). Using GIS for evaluations of neighborhood pedestrian accessibility. Journal of Urban Planning and Development, 123(1), 10-17.

Barreira, A. P., Nunes, L. C., Guimarães, M. H., \& Panagopoulos, T. (2019). Satisfied but thinking about leaving: The reasons behind residential satisfaction and residential attractiveness in shrinking Portuguese cities. International Journal of Urban Sciences, 23(1), 67-87. https://doi.org/10.1080/12 265934.2018.1447390

Beimborn, E. A., Greenwald, M. J., \& Jin, X. (2003). Accessibility, connectivity, and captivity: Impacts on transit choice. Transportation Research Record, 1835, 1-9. https://doi.org/10.3141/1835-01

Bergstad, C. J., Gamble, A., Gärling, T., Hagman, O., Polk, M., Ettema, D., ... \& Olsson, L. E. (2011). Subjective well-being related to satisfaction with daily travel. Transportation, 38(1), 1-15. https:// doi.org/10.1007/s11116-010-9283-z

Bonaiuto, M., Fornara, F., \& Bonnes, M. (2003). Indexes of perceived residential environment quality and neighborhood attachment in urban environments: A confirmation study on the city of Rome. Landscape and Urban Planning, 65(1-2), 41-52. https://doi.org/10.1016/S0169-2046(02)00236-0

Burbidge, S. K. (2012). Foreign living experience as a predictor of domestic travel behavior. Journal of Transport Geography, 22, 199-205. https://doi.org/10.1016/j.jtrangeo.2012.01.002

Buys, L., \& Miller, E. (2012). Residential satisfaction in inner urban higher-density Brisbane, Australia: Role of dwelling design, neighborhood and neighbors. Journal of Environmental Planning and Management, 55(3), 319-338. https://doi.org/10.1080/09640568.2011.597592

Cao, J. (2013). The association between light rail transit and satisfactions with travel and life: Evidence from Twin Cities. Transportation, 40(5), 921-933. https://doi.org/10.1007/s11116-013-9455-8

Cao, X. J., \& Ettema, D. F. (2014). Satisfaction with travel and residential self-selection: How do preferences moderate the impact of the Hiawatha light rail. Journal of Transport and Land Use, 7(3), 93-108. https://doi.org/10.5198/jtlu.v7i3.485

Chadbourne, M. (2014). Residential satisfaction in the changing urban form. In Adelaide: A comparative analysis of Mawson Lakes and Craigburn Farm, South Australia (Ph.D. thesis). University of Adelaide, School of Social Sciences, Adelaide, Australia.

Chapman, D. W., \& Lombard, J. R. (2006). Determinants of neighborhood satisfaction in feebased gated and nongated communities. Urban Affairs Review, 41(6), 769-799. https://doi. org/10.1177/1078087406287164

Chatman, D. G. (2009). Residential choice, the built environment, and nonwork travel: Evidence using new data and methods. Environment and Planning A, 41(5), 1072-1089. https://doi.org/10.1068/ a 4114

Chowdhury, S., Zhai, K., \& Khan, A. (2016). The effects of access and accessibility on public transport users' attitudes. Journal of Public Transportation, 19(1), 97-113. https://doi.org/10.5038/23750901.19.1.7

de Abreu e Silva, J. (2014). Spatial self-selection in land-use-travel behavior interactions: Accounting simultaneously for attitudes and socioeconomic characteristics. Journal of Transport and Land Use, 7(2), 63. https://doi.org/10.5198/jtlu.v7i2.696

de Abreu e Silva, J., \& Goulias, K. (2009). Structural equations model of land-use patterns, location choice, and travel behavior. Transportation Research Record: Journal of the Transportation Research 
Board, 2135, 106-113. https://doi.org/10.3141/2135-13

De Vos, J. (2019). Satisfaction-induced travel behavior. Transportation Research Part F: Traffic Psychology and Behavior, 63, 12-21. https://doi.org/10.1016/j.trf.2019.03.001

De Vos, J., Derudder, B., Van Acker, V., \& Witlox, F. (2012). Reducing car use: Changing attitudes or relocating? The influence of residential dissonance on travel behavior. Journal of Transport Geography, 22, 1-9. https://doi.org/10.1016/j.jtrangeo.2011.11.005

De Vos, J., Ettema, D., \& Witlox, F. (2018). Changing travel behavior and attitudes following a residential relocation. Journal of Transport Geography, 73(October), 131-147. https://doi.org/10.1016/j. jtrangeo.2018.10.013

De Vos, J., Mokhtarian, P. L., Schwanen, T., Van Acker, V., \& Witlox, F. (2016). Travel mode choice and travel satisfaction: Bridging the gap between decision utility and experienced utility. Transportation, 43(5), 771-796. https://doi.org/10.1007/s11116-015-9619-9

Dinç, P., Özbilen, E., \& Bilir, M. B. (2014). A multi-dimensional scale for measuring residential satisfaction (rs) in mass housing projects. Indoor and Built Environment, 23(6), 864-880. https://doi. org/10.1177/1420326X13484619

El-Geneidy, A., Grimsrud, M., Wasfi, R., Tétreault, P., \& Surprenant-Legault, J. (2014). New evidence on walking distances to transit stops: Identifying redundancies and gaps using variable service areas. Transportation, 41(1), 193-210. https://doi.org/10.1007/s11116-013-9508-z

Findlay, A. M. (2011). An assessment of supply and demand-side theorizations of international student mobility. International Migration, 49(2), 162-190. https://doi.org/10.1111/j.14682435.2010.00643.x

Frenkel, A., Bendit, E., \& Kaplan, S. (2013). Residential location choice of knowledge-workers: The role of amenities, workplace and lifestyle. Cities, 35, 33-41. https://doi.org/10.1016/j.cities.2013.06.005

Friman, M., \& Gärling, T. (2001). Frequency of negative critical incidents and satisfaction with public transport services. II. Journal of Retailing and Consumer Services, 8(2), 105-114. https://doi. org/10.1016/S0969-6989(00)00004-7

Glover, P. (2011). A comparison between domestic and international students' trip characteristics: Evidence from an Australian university. Journal of Vacation Marketing, 17(4), 263-274. https://doi. org/10.1177/1356766711420834

Guiver, J. W. (2007). Modal talk: Discourse analysis of how people talk about bus and car travel. Transportation Research Part A: Policy and Practice, 41(3), 233-248. https://doi.org/10.1016/j. tra.2006.05.004

Gunn, L. D., King, T. L., Mavoa, S., Lamb, K. E., Giles-Corti, B., \& Kavanagh, A. (2017). Identifying destination distances that support walking trips in local neighborhoods. Journal of Transport and Health, 5, 133-141. https://doi.org/10.1016/j.jth.2016.08.009

Hair, J. F., Black, W. C., Babin, B. J., \& Anderson, R. E. (2014). Multivariate data analysis. In Statistica Neerlandica (7th ed., Vol. 16, Issue 1). London: Pearson Education Limited. https://doi. org/10.1111/j.1467-9574.1962.tb01184.x

Hinton, P., McMurray, I, \& Brownlow, C. (2014). SPSS explained. London: Routeledge. https://doi. org/10.4324/9781315797298

Hur, M., \& Morrow-Jones, H. (2008). Factors that influence residents' satisfaction with neighborhoods. Environment and Behavior, 40(5), 619-635.

Instituto Nacional de Estatística. (2012). Censos 2011 Resultados Definitivos - Portugal. Lisbon: Instituto Nacional de Estatística.

Kockelman, K. M. (1997). Travel behavior as function of accessibility, land-use mixing, and land-use balance: Evidence from San Francisco Bay Area. Transportation Research Record, 1607, 116-125. 
https://doi.org/10.3141/1607-16

Kuptsch, C., \& Pang, E. F. (Eds.). (2006). Competing for global talent. Brighton, UK: International Institute for Labor Studies.

Langlois, M., van Lierop, D., Wasfi, R. A., \& El-Geneidy, A. M. (2015). Chasing sustainability: Do new transit-oriented development residents adopt more sustainable modes of transportation? Transportation Research Record: Journal of the Transportation Research Board, 2531(2531), 83-92. https://doi. org/10.3141/2531-10

Litman, T. (2007). Land-use impacts on transport (term paper). Retrieved from https://doi. org/10.1007/978-3-642-54876-5

Lotfi, S., Despres, C., \& Lord, S. (2019). Are sustainable residential choice also desirable? A study of household satisfaction and aspirations with regard to current and future residential location. Journal of Housing and the Built Environment, 34(1), 283-311. https://doi.org/10.1007/s10901-018-96314

Lovejoy, K., Handy, S., \& Mokhtarian, P. L. (2010). Neighborhood satisfaction in suburban versus traditional environments: An evaluation of contributing characteristics in eight California neighborhoods. Landscape and Urban Planning, 97(1), 37-48. https://doi.org/10.1016/j.landurbplan.2010.04.010

Lu, M. (1999). Determinants of residential satisfaction: Ordered logit vs. regression models. Growth and Change, 30(2), 264-287. https://doi.org/10.1111/0017-4815.00113

Manaugh, K., \& El-Geneidy, A. M. (2013). Does distance matter? Exploring the links among values, motivations, home location, and satisfaction in walking trips. Transportation Research Part A: Policy and Practice, 50, 198-208. https://doi.org/10.1016/j.tra.2013.01.044

Manaugh, K., \& El-Geneidy, A. M. (2015). The importance of neighborhood type dissonance in understanding the effect of the built environment on travel behavior. Journal of Transport and Land Use, 8(2), 45-57. https://doi.org/10.5198/jtlu.2015.718

Milakis, D., Efthymiou, D., \& Antoniou, C. (2017). Built environment, travel attitudes and travel behaviour: Quasi-Longitudinal analysis of links in the case of Greeks relocating from US to Greece. Sustainability, 9(10), 1774. https://doi.org/10.3390/su9101774

Monteiro, M. M., de Abreu e Silva, J., Haustein, S., \& Pinho de Sousa, J. (2021). Urban travel behavior adaptation of temporary transnational residents. Journal of Transport Geography, 90, 102935. https:// doi.org/10.1016/j.jtrangeo.2020.102935

Muthén, B., \& Asparouhov, T. (2012). Bayesian structural equation modeling: A more flexible representation of substantive theory. Psychological Methods, 17(3), 313-335. https://doi.org/10.1037/ a0026802

Muthén, L. K., \& Muthén, B. O. (2017). MPlus user' guide (8th edition). Los Angeles, CA: Muthén \& Muthén.

Næss, P. (2005). Residential location affects travel behavior - But how and why? The case of Copenhagen metropolitan area. Progress in Planning, 63(2), 167-257. https://doi.org/10.1016/j.progress.2004.07.004

Næss, P. (2014). Tempest in a teapot: The exaggerated problem of transport-related residential selfselection as a source of error in empirical studies. Journal of Transport and Land Use, 7(3), 57-79. https://doi.org/10.5198/jtly.v7i3.491

OECD. (2019). International Migration Outlook 2019 - Chapter 1. In Recent developments in international migration movements and policies (International migration outlook). Paris: OECD. https://doi. org/10.1787/c3e35eec-en

Olsson, L. E., Gärling, T., Ettema, D., Friman, M., \& Fujii, S. (2013). Happiness and satisfaction with work commute. Social Indicators Research, 111(1), 255-263. https://doi.org/10.1007/s11205-012- 
0003-2

Ory, D. T., Mokhtarian, P. L., Redmond, L. S., Salomon, I., Collantes, G. O., \& Choo, S. (2004). When is commuting desirable to the individual? Growth and Change, 35(3), 334-359. https://doi. org/10.1111/j.1468-2257.2004.00252.x

Páez, A., Scott, D. M., \& Morency, C. (2012). Measuring accessibility: Positive and normative implementations of various accessibility indicators. Journal of Transport Geography, 25, 141-153. https:// doi.org/10.1016/j.jtrangeo.2012.03.016

Prato, C. G., Bekhor, S., \& Pronello, C. (2005). Methodology for exploratory analysis of latent factors influencing drivers' behavior. Transportation Research Record, 1926, 115-125. https://doi. org/10.3141/1926-14

Redmond, L. S., \& Mokhtarian, P. L. (2001). The positive utility of the commute: Modeling ideal commute time and relative desired commute amount. Transportation, 28(2), 179-205. https://doi. org/10.1023/A:1010366321778

Riaño, Y., \& Piguet, E. (2016). International student migration. Oxford, UK: Oxford University Press. https://doi.org/10.1093/obo/9780199874002-0141

Salzberger, T., \& Koller, M. (2010). Investigating the impact of cognitive dissonance and customer satisfaction on loyalty and complaint behaviour. Revista Brasileira de Marketing, 9(1), 5-16. https:// doi.org/10.5585/remark.v9i1.2148

Scheiner, J. (2014). Residential self-selection in travel behavior: Toward an integration into mobility biographies. Journal of Transport and Land Use, 7(3), 15-29. https://doi.org/10.5198/jtlu.v7i3.439

Schwanen, T., \& Mokhtarian, P. L. (2004). The extent and determinants of dissonance between actual and preferred residential neighborhood type. Environment and Planning B: Planning and Design, 31(5), 759-784. https://doi.org/10.1068/b3039

Schwanen, T., \& Mokhtarian, P. L. (2007). Attitudes toward travel and land use and choice of residential neighborhood type: Evidence from the San Francisco Bay Area. Housing Policy Debate, 18(1), 171-207. https://doi.org/10.1080/10511482.2007.9521598

St-Louis, E., Manaugh, K., van Lierop, D., \& El-Geneidy, A. (2014). The happy commuter: A comparison of commuter satisfaction across modes. Transportation Research Part F: Traffic Psychology and Behavior, 26(PART A), 160-170. https://doi.org/10.1016/j.trf.2014.07.004

UNESCO. (2020). Education: Outbound internationally mobile students by host region. Retrieved from http://www.sophia.ac.jp/eng/content/download/31978/302437/file/2014_05_gaikokujingauksei.pdf

van Acker, V., Mokhtarian, P. L., \& Witlox, F. (2011). Going soft: On how subjective variables explain modal choices for leisure travel. European Journal of Transport and Infrastructure Research, 11(2), 115-146. https://doi.org/10.18757/ejtir.2011.11.2.2919

Wang, D., \& Lin, T. (2019). Built environment, travel behavior, and residential self-selection: A study based on panel data from Beijing, China. Transportation, 46(1), 51-74. https://doi.org/10.1007/ s11116-017-9783-1

Wolday, F., Næss, P., \& Cao, X. (Jason). (2019). Travel-based residential self-selection: A qualitatively improved understanding from Norway. Cities, 87, 87-102. https://doi.org/10.1016/j.cities.2018.12.029 